\title{
Pelatihan Pemanfataan Botol Bekas Sebagai Media Tanam Hidroponik di Pondok Pesantren Thoriqul Huda
}

\author{
Murniawasih ${ }^{1}$, Mustofa Aji Prayitno ${ }^{2}$, Wirawan Fadly ${ }^{3}$ \\ 1,2,3 IAIN Ponorogo, Ponorogo, Indonesia \\ *Corresponding Author: mustofaajiprayitno@gmail.com
}

\begin{abstract}
Info Artike
Diterima : 28/10/2021

Direvisi: 30/10/2021

Disetujui: 05/11/2021

Abstract. The increasing density of the number of students is feared to cause the land around the Islamic boarding school to accumulate garbage and the environment around the Islamic boarding school to become polluted. As a step to overcome these problems, one of the efforts that can be done is by utilizing the waste produced, for example recycling and reusing plastic bottle waste. At this time, plastic bottle waste can be used as a useful medium, one of which is by farming using hydroponic media by utilizing used plastic bottles that are around Islamic boarding schools. The objectives to be achieved in this community service research are 1) to provide skills to the students on how to make hydroponic planting media without using a large area of land;2) utilize the plastic bottle waste produced into something useful; 3) as an alternative source of food in the form of vegetables for Islamic boarding schools. The method used is the ABCD (Asset Based Community Driven) method which focuses on hydroponic planting using used materials that are around the cottage. The $A B C D$ method is considered appropriate to be applied because it is asset-based which is in line with the potential possessed by Islamic boarding schools. The ABCD method has six stages, namely 1) discovery, 2) dream, 3) design, 4) define, 5) destiny, and 6) reflection. The results of community service research show that with the use of used bottles as hydroponic media, the amount of used plastic bottle waste in Islamic boarding schools can be reduced and it is hoped that it can form a clean and beautiful environment, and the results of hydroponic planting media can be used as an alternative source of energy. food in Islamic boarding schools.
\end{abstract}

Keywords: Hydroponics, Used bottles, Islamic boarding schools

\begin{abstract}
Abstrak. Kepadatan jumlah santri yang semakin meningkat dikhawatirkan dapat menyebabkan lahan yang ada di sekitar pondok pesantren mengalami penumpukan sampah dan lingkungan sekitar pondok pesantren menjadi tercemar. Sebagai langkah untuk mengatasi permasalahan tersebut, salah satu upaya yang dapat dilakukan adalah dengan cara memanfaatkan limbah-limbah yang dihasilkan, contohnya mendaur ulang dan memanfaatkan kembali sampah botol plastik. Pada masa sekarang ini, sampah botol plastik dapat dimanfaatkan menjadi media yang bermanfaat, salah satunya yaitu dengan cara bercocok tanam menggunakan media hidroponik dengan memanfaatkan botol-botol bekas plastik yang ada di sekitar pondok pesantren. Tujuan yang hendak dicapai dalam penelitian pengabdian masyarakat ini adalah 1) untuk memberikan keterampilan kepada para santri cara membuat media tanam hidroponik tanpa menggunakan lahan yang luas; 2) memanfaatkan limbah botol plastik yang dihasilkan menjadi sesuatu yang bermanfaat; 3) sebagai alternatif sumber pangan berupa sayur-sayuran bagi pondok pesantren. Metode yang digunakan adalah metode ABCD (Asset Based Community Driven) yang terfokus pada penanaman hidroponik menggunakan bahan-bahan bekas yang ada di sekitar pondok. Metode ABCD dirasa tepat diterapkan karena berbasis aset yang selaras dengan potensi yang dimiliki oleh pondok pesantren. Metode ABCD memiliki enam tahapan yakni 1) discovery, 2) dream, 3) design, 4) define, 5) destiny, dan 6) reflection. Hasil penelitian pengabdian masyarakat menunjukkan bahwa dengan adanya pemanfaatan botol bekas sebagai media hidroponik ini, maka sampah botol bekas plastik yang ada di pesantren jumlahnya dapat berkurang dan diharapkan dapat membentuk suatu lingkungan yang bersih dan asri, serta hasil dari media tanam hidroponik dapat dimanfaatkan sebagai alternatif sumber pangan di pondok pesantren.
\end{abstract}

Kata Kunci: Hidroponik, Botol bekas, Pondok pesantren.

How to Cite: Murniawasih, M., Prayitno, M.A., \& Fadly, W. (2021). Pelatihan Pemanfataan Botol Bekas Sebagai Media Tanam Hidroponik di Pondok Pesantren Thoriqul Huda. Prima Abdika: Jurnal Pengabdian Masyarakat, 1(4),174-180. https://doi.org/10.37478/abdika.v1i4.1310

(i) (2) Copyright (c) 2021 Murniawasih, Mustofa Aji Prayitno, Wirawan Fadly. This work is licensed undera Creative Commons Attribution-ShareAlike 4.0 International License.

\section{Pendahuluan}

Pondok pesantren Thoriqul Huda merupakan pondok salaf yang terletak di Jalan Syuhada, Desa Cekok, Kecamatan Babadan, Kabupaten Ponorogo Provinsi Jawa Timur. Pesantren ini tercacat memiliki badan hukum di bawah yayasan dengan nama yang sama. Sejak awal berdirinya, pesantren yang didirikan oleh Kiai Dasuki menjadikan sorogan dan mengaji al-Qur'an secara istiqomah sebagai program andalannya. Tidak mengherankan bila banyak santri dari luar daerah termasuk Sumatra berdatangan untuk 
menuntut ilmu di pesantren tersebut. Saat ini, pondok pesantren Thoriqul Huda memiliki kurang lebih 200 santri. Dengan peningkatan jumlah santri yang semakin meningkat setiap tahunnya, maka berdampak pada banyaknya jumlah limbah sampah-sampah plastik yang susah didaur ulang. Melihat banyaknya sampah botol plastik yang dihasilkan, dikhawatirkan dapat mempengaruhi lingkungan di sekitar pondok tersebut. Hal semacam ini banyak dijumpai pada pondok pesantren yang memiliki jumlah santri yang banyak. Apabila sampah tersebut di daur ulang dan bisa di manfaatkan dengan baik, pasti akan menjadi sesuatu yang bermanfaat dan bernilai. Maka dari itu salah satu alternatif cara untuk memanfaatkan hal tersebut adalah dengan memanfaatkan sampah botol plastik melalui media tanaman hidroponik.

Secara umum untuk menjembatani pemanfaatan sampah-sampah nonorganik khususnya pemanfaatan sampah botol plastik, telah mendapat perhatian dari para santri. Dengan adanya tanaman hidroponik di pesantren dapat mempermudah untuk memanfaatkan sampah botol plastik tersebut. Hidroponik dikenal dengan cara menanam tanaman dengan media cair ataupun tanpa tanah, tetapi mengguanakan air, cahaya, rockwool, kapas, tisu, pupuk ataupun nutrisi sebagai medium. Dengan memanfaatkan bahanbahan tersebut, maka akan dapat menggantikan keberadaan tanah. Adapun alat yang digunakan untuk pelatihan tanaman hidroponik diantaranya menggunakan gunting, pisau, pensil, gabus, dan ember (Haifaturrahmah \& Nizaar, 2017). Hal ini ditujukan untuk membantu para santri agar dapat menanam tanaman sayur maupun lainnya yang menjadi bahan makanan sehari-hari, apalagi susahnya perizinan keluar para santri untuk membeli makanan ataupun sayur-sayuran. Dengan adanya tanaman hidroponik di pesantren Thoriqul Huda, diharapkan dapat membantu serta memenuhi kebutuhan serat dalam tubuh para santri dengan mudah dan tercukupi dengan baik.

Salah satu sayuran yang bisa ditanam menggunakan media tanam hidroponik adalah sayuran kangkung dan sawi (Sukaesih et al., 2019). Dengan potensi-potensi aset tersebut dapat memanfaatkannya untuk mendukung terlaksananya pelatihan keterampilan dalam membuat media tanaman hidroponik melalui pemanfaatan botol bekas yang ada di pesantren Thoriqul Huda. Kangkung biasanya tumbuh dengan mudah dan cepat serta memberikan hasil dalam waktu 20-30 hari sesudah dilakukan penanaman. Kangkung juga cocok untuk tanaman hidroponik. Sayuran kangkung juga memiliki beberapa keunggulan serta peluang untuk menanamnya hingga tumbuh dan siap panen juga cukup besar. rasanya enak, segar, dan dapat menyesuaikan ukuran panen yang di inginkan sesuai kebutuhan (Aminah et al., 2020).

Hidroponik sendiri di ambil dari bahasa yunani yaitu hydro yang memiliki arti air dan ponos yang artnya daya (Istiqomah, 2019). Sehingga ketika dua kata tersebut dijadikan satu akan membentuk sebuah pengertian budi daya tanam menggunakan media air. Meskipun hanya di tanam di dalam air, namun tanaman yang di budidayakan dengan tanaman hidroponik ini membutuhkan lebih sedikit air, sehingga penanaman hidroponik sangat cocok di coba pada daerah yang memiliki air sedikit serta banyaknya bahan-bahan bekas botol plastik yang tidak di gunakan lagi (Haifaturrahmah \& Nizaar, 2017). Selain memberi banyak keuntungan bagi para santri. tanaman 
hidroponik perawatannya juga lebih praktis, penggunaan pupuk lebih hemat, gangguan hama lebih terkontrol, tanaman yang mati lebih mudah diganti dengan tanaman yang baru, serta tidak membutuhkan banyak tenaga. Di sisi lain, terdapat beberapa kelemahan mengenai tanaman hidroponik di antaranya adalah investasi awal yang mahal, serta memerlukan keterampilan khusus.

Pada masa pandemi seperti ini, banyak waktu luang yang dapat dimanfaatkan dengan baik. Maka dari itu peneliti bersama pengurus pondok pesantren, akan melakukan pelatihan melalui tanaman hidroponik kepada para santri untuk memanfaatkan sampah-sampah yang tidak bisa di daur ulang yang ada di pesantren. Banyaknya sampah botol plastik yang tidak di manfaatkan ini, dapat digunakan untuk membantu mengembangkan keterampilan santri di pondok pesantren dengan membuat tanaman hidroponik melalui pemanfaatan botol plastik tersebut. Tujuan yang hendak dicapai dalam penelitian pengabdian masyarakat ini adalah 1) untuk memberikan keterampilan kepada para santri cara membuat media tanam hidroponik tanpa menggunakan lahan yang luas; 2) memanfaatkan limbah botol plastik yang dihasilkan menjadi sesuatu yang bermanfaat; 3) sebagai alternatif sumber pangan berupa sayur-sayuran bagi pondok pesantren.

\section{Metode Pelaksanaan}

Metode Pengabdian masyarakat yang digunakan dalam penelitian pengabdian masyarakat ini adalah menggunakan pendekatan ABCD (Aset Based Community Driven). Kegiatan pengabdian masyarakat ini lebih difokuskan pada proses pelatihan dan pendampingan maupun penyuluhan pembuatan alat atau bahan yang ada di sekitar lingkungan pondok pesantren. Penelitian ini di awali dari sebuah temuan aset atau potensi yang akan dikembangkan. Pesantren juga merupakan aset yang berharga bagi pendidikan di Indonesia khususnya pendidikan Islam. Peran metode ABCD ini di rasa sesuai untuk memfasilitasi pelatihan dan pendampingan pembuatan tanaman hidroponik karena metode ABCD ini lebih mengutamakan pemanfaatan potensi dalam pondok pesantren dan dalam diri para santri serta aset-aset lingkungan fisik. Potensi dalam diri santri yang di maksud disini adalah segala keterampilan para santri yang dapat dikembangkan dalam membuat media tanaman hidroponik melalui botol bekas.

Metode pendekatan untuk pelaksanaan kegiatan pengabdian pada masyarakat yang dilakukan bersifat partisipasi aktif para santri-santri Thoriqul Huda dalam merencanakan dan menjalankan program-program kegiatan yang disepakati bersama. Dalam rangka untuk mencapai tujuan yang di harapkan, maka di susunlah tahapan kegiatan dari mulai persiapan, pelaksanaan, pelatihan, dan pendampingan secara bertahap. Dalam metode ABCD, memiliki enam tahapan yakni 1) discovery, 2) dream, 3) design, 4) define, 5) destiny, dan 6) reflection.

Tahap pertama adalah tahap menemukan atau (discovery). Proses menemukan ini dilakukan melalui penggalian potensi aset yang terdapat di lingkungan pesantren Thoriqul Huda di wilayah Cekok, Babadan, Ponorogo. Penentuan aset juga disesuaikan dengan situasi kondisi dan keadaan yang ada di Pesantren Thoriqul Huda. Proses ini dilakukan melalui proses observasi maupun wawancara tehadap santri Thoriqul Huda. Bila tahap ini 
berhasil maka langkah-langkah selanjutnya tidaklah sulit (Munggoro \& Budhita, 2008).

Tahap kedua adalah bermimpi atau (dream). Memimpikan masa depan dengan cara kreatif melihat masa depan yang dapat mendorong perubahan yang mungkin terwujud. Tahap ini mendorong para santri menggunakan imajinasinya untuk membuat gambaran positif di masa depan mereka. Pada tahap ini, harapan dan impian para santri Thoriqul Huda adalah agar bisa memanfaatkan dan mengembangkan keterampilan terkait kegiatan yang ada di pesantren Thoriqul Huda.

Tahap ke tiga yaitu tahap merancang atau (design). Para santri terlibat dalam proses belajar, tahap merancang ini bertujuan untuk memberikan solusi dalam permasalahan-permasalahan yang ada dan dapat memfasilitasi santri untuk bersosialisasi dan mengembangkan keterampilannya.

Pada tahap keempat dari metode ABCD yang dilakukan yaitu tahap (define). Pada tahap ini di tentukan suatu tindakan atau pengamatan yang perlu dilakukan berdasarkan aset yang dimiliki. Tahap ini lebih mudah dalam memulai proses perancangan memperluas pengetahuan sehingga dapat memberi solusi-solusi yang baik dan memungkinkan (Natalia, Kusumarini \& Poillot, 2017). Tujuan dari proses pencarian yang diinginkan dapat memanfaatkan waktu untuk mengenal orang-orang dan tempat dimana perubahan akan dilakukan.

Tahap selanjutnya yaitu tahap melakukan atau (destiny). Pada tahap ini dilakukan kegiatan yang sudah disepakati untuk memenuhi impian para santri dalam meningkatkan keterampilan santri dengan memanfaatkan botol bekas yang ada. Partisipan dalam kegiatan pengabdian masyarakat ini di ikuti sebanyak 10 orang santri. kegiatan pelatihan dan pendampingan akan dilakukan dalam 3 kali pertemuan dengan rincian yaitu pelatihan 1 pertemuan dan pendampingan 2 pertemuan. Kegiatan pelatihan ini dilakukan menggunakan metode caramah, diskusi. Pelatihan dan pendampingan dengan tujuan untuk menambah pengetahuan para santri tentang bahan, alat dan tahapan penanaman tanaman hidroponik bagi santri Thoriqul Huda. Sedangkan kegiatan pendampingan dilakukan dengan mendampingi para santri dalam pembuatannya, dengan tujuan untuk menguatkan keterampilan santri dalam membuat tanaman hidroponik.

Reflection merupakan tahap akhir yang bertujuan untuk mengetahui sejauh mana perubahan pada masyrakat untuk menunjang terjadinya transformasi sosial telah terjadi. Pada kegiatan ini dilakukan di akhir kegiatan melalui pengamatan dengan menggunakan lembar observasi atau pengumpulan data dengan fokus pada motivasi dan minat para santri, kualitas produk yang dihasilkan, dan kelanjutan pembuatan berupa hidroponik secara mandiri.

\section{Hasil dan Pembahasan}

Kegiatan ini telah dilaksanakan mulai tanggal 5 Juli sampai dengan 13 Agustus 2021. Langkah awal yang dilakukan oleh peneliti adalah melakukan observasi awal di ponpes Thoriqul Huda dengan melihat kondisi yang ada di pondok pesantren tersebut. Peneliti memutuskan adanya pelatihan keterampilan terhadap para santri-santri. Pelatihan keterampilan hidroponik ini memiliki tujuan yang mengarah kepada para santri untuk lebih 
meningkatkan kemampuan keterampilannya untuk memanfaatkan sampah botol plastik serta pemahaman tentang hidroponik. Pelaksanaan pengabdian di mulai sejak di terimanya usulan pengabdian kepada para santri oleh pengasuh. Pemanfaatan botol bekas adalah salah satu cara yang bisa dilakukan oleh seluruh masyarakat untuk menjaga kelestarian lingkungan pondok khususnya para santri Thoriqul Huda. Cara sederhana yang dapat diterapkan di pondok pesantren adalah dengan memanfaatkan botol bekas plastik sebagai media tanam dengan sistem hidroponik. Kegiatan ini selain untuk meningkatan kesadaran lingkungan bagi santri juga dapat dimanfaatkan sebagai media pembelajaran untuk menambah pengetahuan serta keterampilan santri.

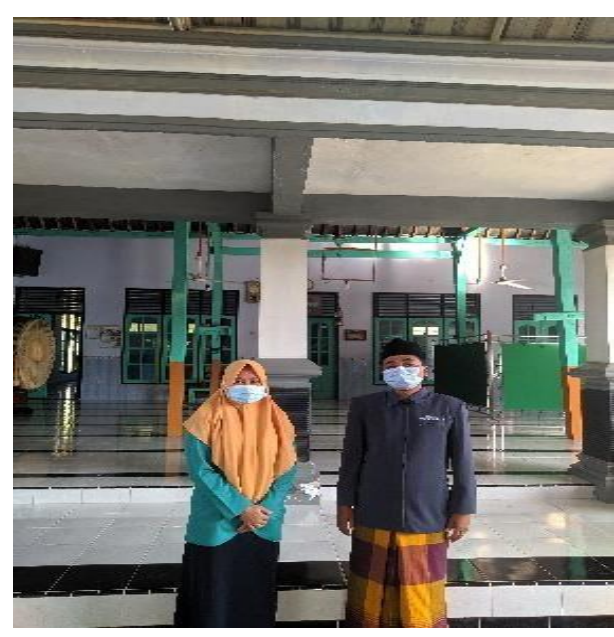

Gambar 1. Sowan ke Pengasuh Pondok Pesantren

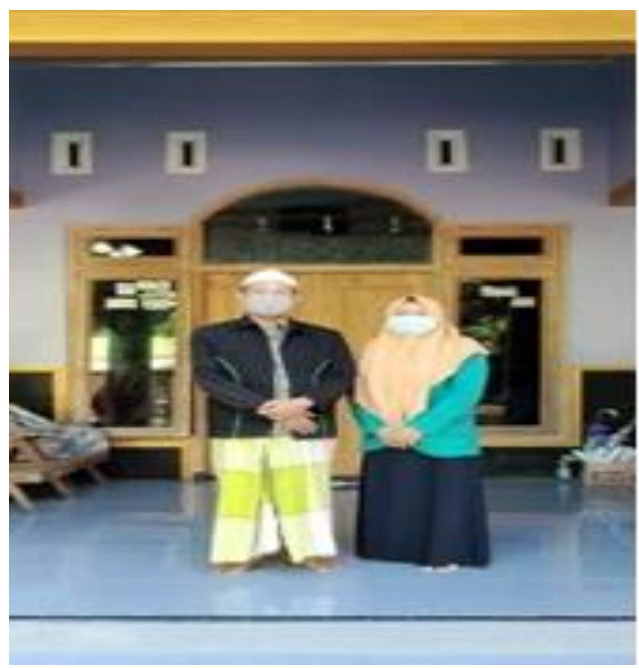

Gambar 2. Sowan Kepala Pondok

Sebelum kegiatan berlangsung terlebih dahulu kita mengetahui tingkat pengetahuan dan pemahaman para santri tentang cara bercocok tanam dengan cara hidroponik menggunakan bahan botol bekas. Kegiatan pengabdian yang dilakukan pertama adalah menanam benih biji kangkung dan sawi di atas kapas yang sudah berisikan air. Setelah itu tunggulah sampai beberapa hari sampai biji tersebut sudah tumbuh menjadi kangkung kecil lalu di pindahkan ke botol bekas yang sudah berisikan kapas dan air.

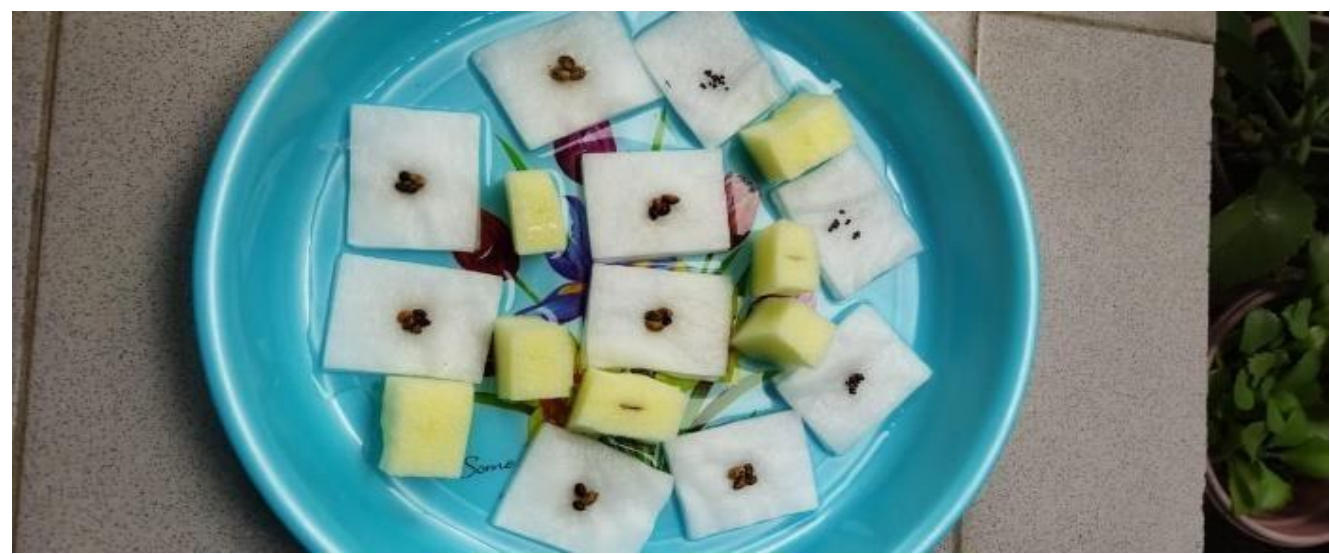

Gambar 3. Benih biji kangkung dan sawi yang akan digunakan untuk penanaman hidroponik 
Pada pelaksanaan kegiatan pelatihan tanaman hidroponik kangkung dan sawi yang dilakukan, peserta pelatihan diberikan keleluasan dan kemudahan untuk bertanya sebanyak mungkin pada saat pelatihan sedang berlangsung, terjalinnya komunikasi yang baik antara pemateri dan peserta pelatihan diharapkan dapat memaksimalkan kegiatan pelatihan. Adapun kendala yang dihadapi adalah peserta kegiatan yang terbatas, pemeliharaan hidroponik agak sulit, memerlukan keterampilan khusus, investasi awal yang mahal, dan pelaksanaan kegiatan harus menerapkan protokol kesehatan sesuai dengan ketentuan yang berlaku. Melihat kondisi saat ini perlu adanya pertimbangan untuk mencari cara yang tepat dalam melakukan upaya untuk mengembangkan keterampilan para santri Thoriqul Huda, Cekok, babadan, Ponorogo untuk ke depannya.

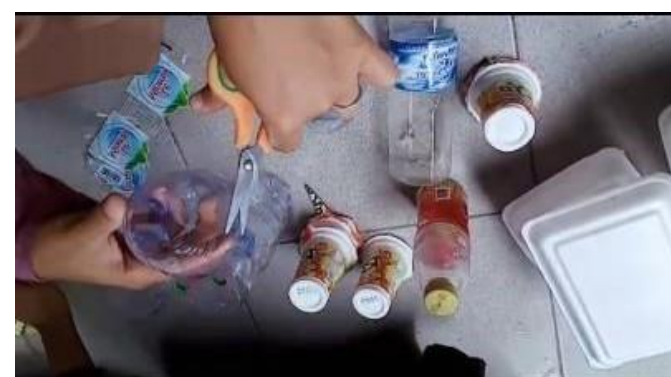

Gambar 4. Proses pengelolaan botol bekas

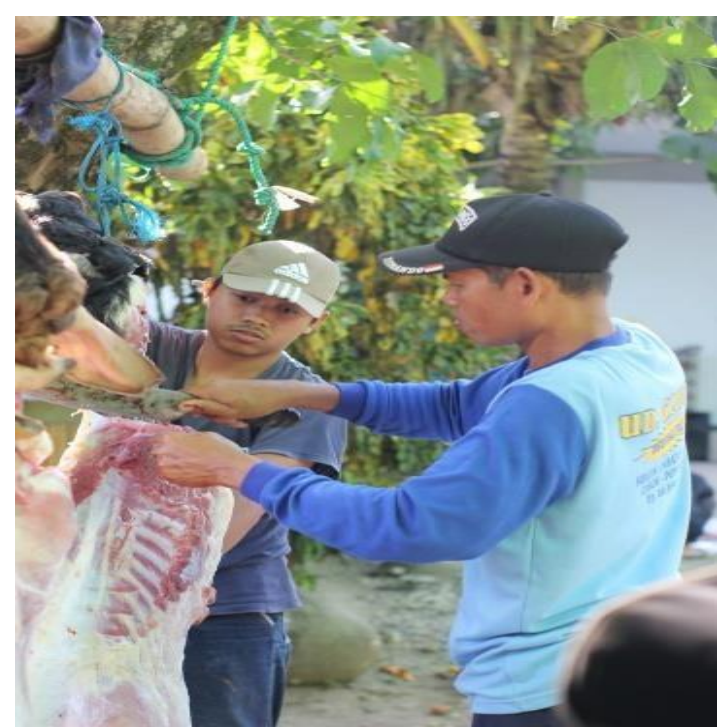

Gambar 6. Membantu penyembelihan hewan qurban

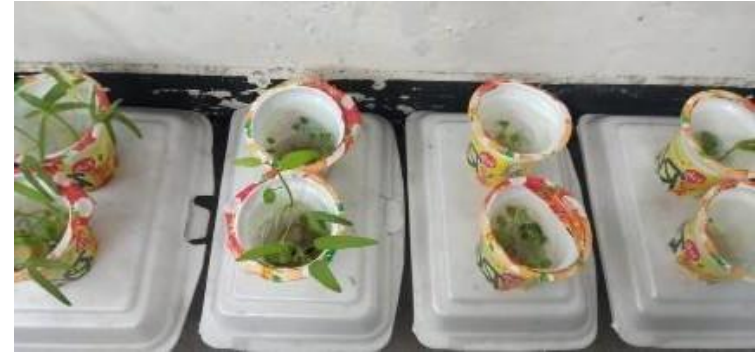

Gambar 5. Penanaman biji kangkung dan sawi

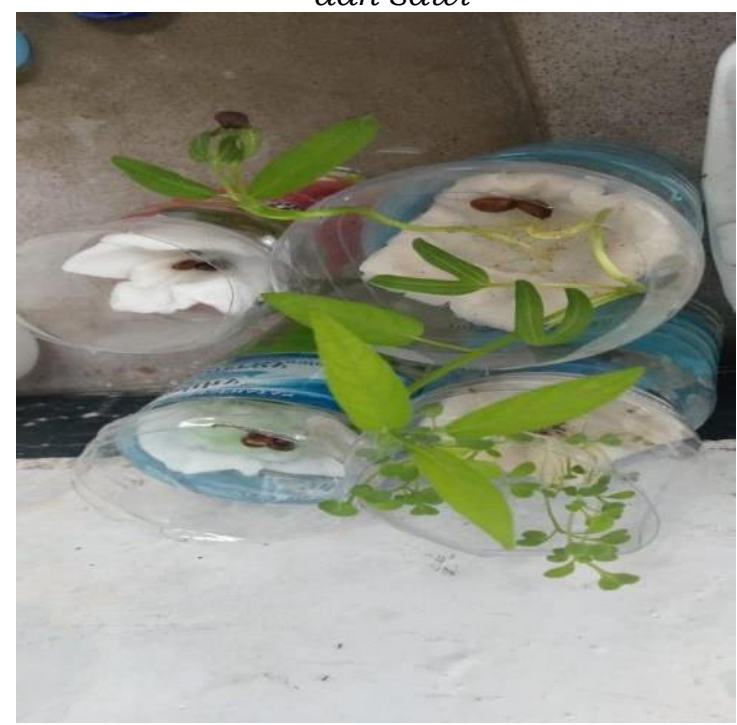

Gambar 7. Tanaman hidroponik

Pelaksanaan kegiatan secara keseluruhan dievaluasi untuk mengetahui sejauh mana tingkat keberhasilan pelatihan di tinjau dari tingkat kepuasan para santri dalam mengikuti kegiatan pelatihan hidroponik. Kepuasan para santri yang di maksud di tinjau dari segi pemateri dan praktik. Hal tersebut sangat diperlukan guna meningkatkan kepuasan santri pada kegiatankegiatan pengabdian yang sejenis.

Secara umum kepuasan para santri berada pada kategori puas dan cukup puas. Dari tanggapan para santri secara langsung terhadap kegiatan, para santri menyatakan puas dan cukup puas dengan kegiatan yang telah 
dilakukan dan materi yang telah diberikan. Peserta menyatakan bahwa Kegiatan pengabdian dapat memberikan manfaat yang besar antara lain dapat meningkatkan pengetahuan, serta keterampilan dalam membuat tanaman hidroponik melalui pemanfaatan botol bekas.

\section{Simpulan dan Tindak Lanjut}

Pelaksanaan penelitian dan pengabdian masyarakat pelatihan pemanfaatan sampah botol plastik bekas sebagai media tanaman hidroponik di Pondok Pesantren Thoqirul huda telah terlaksana sesuai dengan perencanaan yang telah dibuat dan dirancang. Secara umum berdasarkan hasil wawancara pada tahap evaluasi, para peserta yakni santri Thoriwul Huda merasa puas dengan pelaksanaan pelatihan. Peserta menyatakan bahwa Kegiatan pengabdian dapat memberikan manfaat yang besar. Dengan adanya pemanfaatan botol bekas sebagai media hidroponik ini, maka sampah botol bekas plastik yang ada di pesantren Thoriqul Huda jumlahnya dapat berkurang dan diharapkan dapat membentuk suatu lingkungan yang bersih dan asri, serta hasil dari media tanam hidroponik dapat dimanfaatkan sebagai alternatif sumber pangan di pondok pesantren.

\section{Daftar Pustaka}

Aminah, I. S., Rosmiah, R., Hawalid, H., Yuningsih, L., \& Helmizuryani, H. (2020). Penyuluhan Budidaya Tanaman Sayur Kangkung (Ipomoea reptans) melalui Sistem Hidroponik di Kelurahan Alang-Alang Lebar Kota Palembang. Altifani Journal: International Journal of Community Engagement, 1(1), 46-52.

Haifaturrahmah, H., \& Nizaar, M. (2017). Pemanfataan Botol Plastik Bekas sebagai Media Tanam Hidroponik dalam Meningkatkan Kesadaran Siswa Sekolah Dasar terhadap Lingkungan Sekitar. JMM (Jurnal Masyarakat Mandiri), 1(1), 10-16.

Istiqomah, S. (2019). Menanam Hidroponik. Yogyakarta: Azka Press.

Munggoro, D. W. dan Budhita K. (2008). Panduan Fasilitator. Indonesia Australia Partnership: IDSS Acces Phase II.

Natalia, C., Kusumarini, Y., \& Poillot, J. F. (2017). Perancangan Interior Fasilitas Edukasi Hidroponik di Surabaya. Intra, 5(2), 97-106.

Sukaesih, S., Ismayati, I., Lestari, M., Widiyah, G. A., \& Zamzami, I. R. (2019). PENINGKATAN KREATIFITAS SANTRI MELALUI PROGRAM PENGOLAHAN TANAMAN HIDROPONIK. Lembaran Masyarakat: Jurnal Pengembangan Masyarakat Islam, 5(01), 15-34.

Tim LPPM IAIN Ponorogo (2021). Buku Pedoman KPM Daring Dari Rumah (KPM-DDR). Ponorogo: LPPM IAIN Ponorogo. 